chief demand of the present time is for 'spade workers' and 'quarrymen' to prepare foundations and material." It is to be hoped that on this point at least the Board will allow itself to be converted. Unless men of outstanding ability can be attracted to the research stations and agricultural colleges, there is not much hope that the taxpayer will see anything like the return he ought for the money expended. This, indeed, is the vital question; if the right sort of men are got to do the work all the other questions of administration sink into insignificance. But here also the Board is on what appears to be the safes ground. The idea of a central experimental station is dismissed, and a wider policy is suggested :- "It would probably be advisable, therefore, to use part of the Develofment Fund in making such grants to universities and university colleges as would induce them to make provision for agricultural research."

At no period in its history has agricultural science had a greater opportunity than at present. It is no longer hampered by lack of funds or by apathy on the part of the farmer. The problems are more numerous and more interesting than ever they were. But unfortunately the workers are few, and fresh workers are not readily forthcoming. The hopeful feature is that a number of eminent men of science are giving up time and thought to the organisation of the new work, and, further, that the Board of Agriculture and the large agricultural societies are manifestly and genuinely anxious to render all the help they can.

\section{RATS AND PLAGUE.}

A LTHOUGH the recent epidemics of bubonic A plague in China, India, and other parts of the world have been always associated with outbreaks of the same disease amongst rats, the historical study of plague throughout the world reveals the singular fact that previous to 1800 very few references to a coincident mortality amongst rats have been put on record. Many excellent accounts of the older outbreaks, notably of the Black Death in Europe in 1347, and the Great Plague of London in $16_{5}$, are in existence, but careful research into these documents by modern historiographers--Haeser, Hirsch, Abel, and Stickerhas shown that for reasons difficult to discover very scanty mention of associated rat mortality has been made.

The earliest recorded instance is perhaps that given in the Bible in the account of the pestilence amongst the Philistines, which they ascribed apparently to "the mice that marred the land." Avicenna refers to the association between rats and plague in his description of the epidemic in Mesopotamia about the year Iooo A.D. Nicephorus Gregoras, writing of the Great Plague of 1348 , which entered Europe by way of Constantinople, makes a similar reference. Rats are mentioned in connection with the plague in Yunnan about 1757 , and later in $187 x-3$. In India an association between rats and plague is noted in the Bhagavata Purana, by the Emperor Jehangir in the plague epidemic of $1_{6} 1_{5}$, and in a report of the Pali plague in Rajputana in 1836 . Lastly, Orraeus refers definitely to rat mortality in his account of the epidemic of $177 x$ in Moscow.

The identity of the disease in rats with that affecting man was established by the discovery in 1894 of $B$. pestis by Yersin and Kitasato.

Within the next few years the relationship between rat and human plague was investigated in many parts of the world-by Thompson and Tidswell in Sydney, Clark and Hunter in Hongkong, Snow, Weir, Hankin and James in India, and by Kitasato in Japan. In I905 the Plague Research Commission was appointed to investigate plague in India, and the reports of this NO. 2 I 4O, VOL. 85$]$
Commission represent the results of the most exhaustive inquiry into the subject that has yet been carried out.

The Commission early turned its attention to the relationship of rat plague and human plague, and instituted an extensive examination of the rats in Bombay and elsewhere for the presence of plague infection. The maps and charts, representing graphically the results of this examination, clearly show the correlation between the epizootic and the epidemicthe rat epizootic preceding the epidemic by an interval of ten to fourteen days. Every outbreak of bubonic ${ }^{1}$ plague, when adequately investigated, was found to be associated with the disease amongst rats. The conclusion must be drawn that every epidemic of bubonic plague is caused by the concomitant rat plague.

In Bombay the rat population is an enormous one, Mus decumanus (the brown or grey rat) swarming in the sewers, gullies, and outhouses in the city, and Mus rattus (the black rat) living in countless numbers in the houses of the people. The latter species is of especial importance in plague epidemics, because it is essentially a house rat: it may almost be said to be a domesticated animal. The severity of the epizootics in the two species will be appreciated when it is stated that during one year the examination of $70,789 M$. decumanus, taken from all parts of Bombay city, proved that 13,277 were plague-infected $=18.8$ per cent., and that out of $46,302 M$. rattus examined $4,38 \mathrm{I}$ were plague-infected $=9^{\circ} 4$ per cent. The heavier incidence of plague in $M$. decumanus is explicable ty the circumstance that the flea infestation of this species is more than twice that of $M$. rattus.

Some interesting observations on the distribution of different species of rats in India have been made recently by Captain R. E. Lloyd, I.M.S. The most common rats in India are $M$. rattus, $M$. decumanus, and Gunomys (Nesokia bengalensis). $M$. decumainus is common both in Bombay and Calcutta, but is absent from the city of Madras. It is significant that Madras is the one port in India which has never been seriously infected with plague. $M$. rattus appears to be universally distributed in India, whereas $M$. decumanus does not seem to occur in India except in seaports. Nesokia bengalensis is found in every part of India.

The question of the transportation of plague by ship rats is an extremely important one, but has not so far been thoroughly worked out. It would appear that $M$. decumanus is the species most commonly infesting ships, although $M$. rattus is also found.

Sticker, in his history of plague epidemics, quotes the statement that $M$. decumanus got into Europe from Persia about the year 1725. In England $M$. rattus was displaced bv the invasion of $M$. decumanus about this time. At the present day the predominating species in this country is undoubtedly $M$. decumanus; $M$. rattus is, however, becoming increasingly common in the seaports.

An important question in plague epidemiology is the mode of conveyance of the infective organism from the plague rat to man. It is impossible even to summarise here the numerous experiments and observations on this subject, but it may be said that from many sides, and especially from experiments in the laboratory and in actual plague-infected houses, a mass of evidence has been raised which incriminates and indeed convicts the rat flea as the transmitting agent of the infection.

1 Pneumonic plague differs from bubonic plagve in its mode of spread. When a series of cases of plague pneumonia occurs, the infertive organims are conveyed directly from case to rase by coughing and inhalation. It is probable that the usual sonrce of infection in the first case of the series is a severe secondary pneumonia occurring in a patient with septicæmic plague. 
In India the rat flea, Loemopsylla cheopis, which clusely resembles the human flea, Pulex irritans, in appearance, is by far the most commonly found species. In England the common rat flea is Ceratophyllus fasciatus; a single specimen only of L. cheopis has been found up to the present time.

$L$. cheopis, especially if hungry, will bite man; $C$. fasciatus does not take to man with any readiness, but will undoubtedly bite on occasion. This difference in the appetite of the two species for human blood may be of significance in determining the likelihood of the spread of rat plague to human beings.

G. F. Petrie.

\section{PROF. D. P. PENHALLOW.}

WE regret to announce that Prof. D. P. Penhallow, D.Sc., F.R.S. (Canada), president of the American Society of Naturalists, and professor of botany in McGill University, Canada, died on October 20, in consequence of an apoplectic seizure, whilst on board the ss. Lake Manitoba, on voyage to Liverpool. His remains were brought to Liverpool, and were, in accordance with his wishes, cremated at Anfield Cemetery on Friday, October 28. Prof. and Mrs. Penhallow were about to begin a year's vacation, and had intended spending the winter in the south of England. In consequence of the severe strain of work which Prof. Penhallow had undergone during the last few years, his previously excellent health had shown signs of giving way, and under medical advice he was about to take a prolonged rest, when the lamentable event of his decease occurred.

Prof. D. P. Penhallow was born in 1854 at Kittery Point, in Maine, where his parents had a summer cottage, but their home was in New Hampshire, and Prof. Penhallow always regarded himself as a New Hampshire man. His family were in the direct line of descent from Governor Wentworth, of pre-Revolutionary days, and Prof. Penhallow was a splendid embodiment of the best type of New Englander. He received his scientific education in Boston University, and after graduation he was offered the post of professor of botany in the Imperial College of Agriculture in Japan. In the same year (1876) he married Miss Sarah Dunlap, who, like himself, could boast of a distinguished New England ancestry, and the first four years of his married life were spent in Japan. He thus enjoyed the distinction of being one of the group of Western students who were chosen by the Reformed Japanese Government to inaugurate the epoch of Meiji (intellectual enlightenment) in Japan.

Returning to America in 1880 , he undertook work in connection with the summer school of botany in Harvard University, and in $188_{3}$ he was offered the newly-created chair of botany in McGill University, Montreal, where the rest of his professional life was spent. He had a very uphill fight in Montreal, which he manfully fought. There was no botanical laboratory and there were no funds to provide one; but as Prof. Penhallow gained the respect and esteem of the community help was forthcoming, and before he died the botanical laboratory was exceedingly well equipped. When he was appointed obscurantist views prevailed in Montreal, both in the city and in the University, and Prof. Penhallow was one of the very first to teach evolution, and may thus be said to have helped to inaugurate the epoch of "meiji" in Montreal. In his own science he devoted special attention to the anatomy of woods, both recent and fossil; on this subject he published many valuable papers, and in his great work on "Gymnosperms," which appeared in 1908 , he summed up the results of twenty years' labour. His eminence in his special department was NO. 2 I 40 , VOL. 85$]$ cordially recognised by the American scientific world, and when he died he was not only president of the American Society of Naturalists, but vice-president of the American Society of Botanists.

But Prof. Penhallow's activities were by no means limited to teaching in his special subject. He threw himself into every movement calculated to bring a wider intellectual outlook into Montreal and Canada generally. He instituted courses of lectures to teachers, which had for many years a beneficial effect on those engaged in instruction in the public schools of the city. He was a leading member of the Canadian Royal Society, and in 1897, when the British Association met in Toronto, he was appointed a member of a committee to impress on the Canadian Government the desirability of founding a marine biological station. The Government acted in accordance with the advice of this committee, and in 1899 a small floating station was started, which was moved from placed to place in eastern Canadian waters.

When in 1907 the Government was persuaded to give a grant towards the foundation of a permanent station at St. Andrews, Prof. Penhallow was deputed by the Biological Board to supervise its erection. When he arrived at St. Andrews it was found to be necessary not only to build the station, but to cut a road through a mile of forest and to build a wharf. No one was ready to undertake the contract for this work, and those who were ready to undertake part of it, when they discovered that it was to be paid for by "Government money," would only do so at exorbitant prices. With characteristic American energy and versatility, Prof. Penhallow threw himself into the breach, became contractor himself, and constructed the road, the station, and the wharf in one-third the time he was told it would require, and at a great saving in cost. Next year he superintended the activities of the station, but is political crisis at Ottawa temporarily stopped supplies, and the anxiety and financial strain which he underwent undermined his health, and, in the opinion of his friends, constituted the first link in the chain of causes which led to his death.

Prof. Penhallow is survived by his wife and by his son, Dr. P. Penhallow, who is engaged in medical practice in Boston. By his death McGill University loses one of its most distinguished professors, the city of Montreal one of its most publicspirited citizens, and the science, not only of botany, but of marine biology generally, a devoted supporter who could ill be spared.

E. W. M.

\section{NOTES.}

WE learn with great regret that it has been found necessary to postpone the festivities arranged to take place at Leyden to-day (November 3). On this date Prof. van Bemmelen completes his eightieth year, and he was to have received the personal congratulations of friends and disciples from all parts of the world. Owing to his illness, the ceremony is to be confined to the formal presentation of the jubilee volume by Prof. Lorentz, if, as is hoped, Prof. van Bemmelen is sufficiently recovered to receive him. The jubilee volume is a remarkable testimony to the regard which is felt throughout the world for the distinguished second founder of colloidal chemistry. It contains a portrait, together with a biography and a bibliography of the professor's published works. Sixty papers on subjects connected with the colloidal state have been contributed by workers from all parts of the world. Amongst the authors are le Chatelier, Duhem, Zsigmondy, Liesegang, von Wiemarn, Hissink, Freundlich, Biltz, Spring, Hardy, Svedborg, Jordis, Wolf. Ostwald, Lotter- 